Published by LPMP Imperium

Journal homepage: https:/ / ejournal.imperiuminstitute.org/ index.php/ AKURASI

\title{
PENGARUH KEBIJAKAN DIVIDEN TERHADAP VOLATILITAS HARGA SAHAM DENGAN INFLASI SEBAGAI VARIABEL MODERASI
}

\author{
Patricia Maurin Aten*, Dade Nurdiniah \\ Fakultas Bisnis Institut Teknologi dan Bisnis Kalbis, Jakarta, Indonesia
}

AKURASI

85

\begin{abstract}
This study aims to analyze the effect of dividend payout ratio and dividend yield on stock price volatility with inflation as a moderating variable in manufacturing companies listed on the Indonesia Stock Exchange for the period 2013-2017. Documentary data (secondary) from financial statements and annual reports are used in this study. The population of this study includes manufacturing companies listed on the Stock Exchange from 2013-2017 and IPOs at least from 2013. The sampling method used in this study was purposive sampling, of which 44 companies were included in the criteria of this study. The analytical method carried out in this study is multiple regression. The results show that the variable that has a significant influence on stock price volatility is only the dividend payout ratio. The more dynamic the dividend payout ratio, the higher the stock price volatility, and vice versa. Research also shows the results that the inflation variable does not moderate the effect of dividend payout ratio and dividend yield on stock price volatility
\end{abstract}

\begin{abstract}
Abstrak
Penelitian ini bertujuan untuk menganalisis pengaruh dividend payout ratio dan dividend yield terhadap volatilitas harga saham dengan inflasi sebagai variabel moderasi pada perusahaan manufaktur yang terdaftar di Bursa Efek Indonesia periode 2013-2017. Data dokumenter (sekunder) dari laporan keuangan dan annual report digunakan dalam penelitian ini. Populasi penelitian ini meliputi perusahaan manufaktur yang terdaftar di BEI dari tahun 2013-2017 dan IPO setidaknya dari tahun 2013. Metode pengambilan sampel yang digunakan dalam penelitian ini adalah purposive sampling, yang mana terdapat 44 perusahaan yang masuk dalam kriteria penelitian ini. Metode analisis yang dilakukan dalam penelitian ini adalah regresi berganda. Hasil penelitian menunjukkan bahwa variabel yang memiliki pengaruh signifikan terhadap volatilitas harga saham hanyalah dividend payout ratio. Semakin dinamis dividend payout ratio, maka semakin tinggi volatilitas harga saham, dan sebaliknya. Penelitian juga menunjukkan hasil bahwa variabel inflasi tidak memoderasi pengaruh dividend payout ratio dan dividend yield terhadap volatilitas harga saham.
\end{abstract}

Email korespondensi: maurinaten36@gmail.com

Pedoman Sitasi: Aten, P., \& Nurdiniah, D. (2020). PENGARUH KEBIJAKAN DIVIDEN TERHADAP VOLATILITAS HARGA SAHAM DENGAN INFLASI SEBAGAI VARIABEL MODERASI Variabel Moderasi. AKURASI: Jurnal Riset Akuntansi Dan Keuangan, 2(2), 85 - $94 . \quad$ DOI: https:/ / doi.org/ 10.36407/ akurasi.v2i2.192

\section{Paper type}

Accounting and finance, Research paper

Received: 23 Jun 2020

Revised: 05 Jul 2020

Accepted: 09 Jul 2020

Online: 10 Jul 2020

Keywords: dividend payout ratio, dividend yield, stock price volatility, inflation

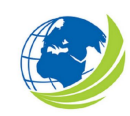

Akurasi: Jurnal Riset Akuntansi dan Keuangan, Vol 2, No.2, Agustus 2020, pp. 85 - 94

eISSN: 2685-2888 


\section{PENDAHULUAN}

Perusahaan pada dasarnya memiliki tujuan untuk memperoleh keuntungan sebanyak-banyaknya dan mengembangkan perusahaan tersebut ke dalam skala yang lebih besar, untuk mencapai tujuan tersebut perusahaan perlu melakukan perencanaan mengenai langkah yang akan diambil baik jangka pendek maupun jangka panjang. Perencanaan ini salah satunya dapat mencakup kegiatan ekspansi dengan perusahaan lain, memperluas target pasar, atau memperbanyak sektor bisnis, dan sebagainya. Perusahaan harus memiliki modal yang mampu menunjang proses pencapaian tujuan tersebut. Beberapa cara untuk memperoleh modal dapat dilakukan dengan memperoleh pinjaman kepada kreditur atau berkecimpung di dunia pasar modal.

Menurut Widoatmodjo (2015:16), pasar modal dapat dikatakan pasar abstrak, dimana yang diperjualbelikan adalah dana-dana jangka panjang, yaitu dana yang ketertarikannya dalam investasi lebih dari satu tahun. Pasar modal memberikan peluang dan keuntungan yang besar bagi perusahaan untuk mem-peroleh dana serta melakukan ekspansi, namun terdapat unsur ketidakpastian serta resiko yang besar di dalam pasar saham. Salah satu hal yang diperjualbelikan di pasar modal adalah saham. Saham adalah bentuk kepemilikan seseorang atau badan dalam suatu perusahaan. Saham berbentuk selembar kertas yang berisi bukti kepemilikian orang atau badan tersebut, kepemilikan setiap subyek berbeda-beda tergantung berapa lembar saham yang ia beli (Darmadji dan Fakhruddin, 2012:5). Saham sebuah perusahaan beredar terus menerus setiap harinya dengan harga yang terus berubah-ubah.

Daya tarik dari investasi saham sendiri adalah perolehan keuntungan berupa capital gain dan dividen. Investor akan mengaharapakan return yang setimpal bahkan lebih besar dari jumlah kekayaan yang telah diinvestasikan ke perusahaan tersebut. Capital gain merupakan selisih antara harga jual dan harga beli sedangkan dividen adalah pengembalian baik berupa kas maupun saham terhadap investor. Setiap perusahaan memiliki kebijakan dividen yang berbeda, kebijakan dividen diartikan sebagai keputusan yang diambil perusahaan terkait pembagian dividen, seperti berapa jumlahnya, bentuk dividen yang dibagikan dan tanggal pembagian. Kebijakan dividen diukur dengan menggunakan dua ukuran yaitu dividend yield (DY) dan dividend payout ratio (DPR). Kedua ukuran ini menggambarkan hal yang berbeda, dividend yield menggambarkan besarnya pengembalian pendapatan yang diperoleh investor berdasarkan jumlah kekayaan yang diinvestasikan, sedangkan dividend payout ratio menunjukkan besarnya nilai yang diambil dari laba bersih perusahaan untuk pembayaran dividen. Informasi terkait saham merupakan kabar yang menarik bagi investor karena dapat menjadi bahan pertimbangan mereka atas saham suatu perusahaan.

Menurut Khurniaji dan Raharja (2013: 2), volatilitas saham adalah pergerakan naik turunnya harga saham di dalam bursa efek. Semakin tinggi volatilitas akan menghasilkan resiko tinggi yang berbanding lurus dengan peluang memperoleh keuntungan bagi investor. Salah satu faktor yang mempengaruhi volatilitas harga saham adalah inflasi, inflasi menyebabkan kenaikan terus menerus akan harga suatu barang, masyarakat akan kesulitan untuk memperoleh barang sehingga menyebabkan bisnis macet, hal ini tentu menjadi pokok perhatian investor sebelum membeli saham suatu perusahaan agar tidak mengalami kerugian.

Penelitian Kharinda (2018) memperoleh hasil bahwa Dividend Payout Ratio berpengaruh namun tidak signifikan terhadap volatilitas harga saham sedangkan profitabilitas berpengaruh dan signifikan terhadap volatilitas harga saham. Penelitian lain yang dilakukan oleh Azura, Sofia, Nurhasanah (2018) menunjukkan hasil yaitu Dividend Yield, Ukuran perusahaan, volume perdagangan, inflasi, dan tingkat suku bunga tidak berpengaruh terhadap volatilitas harga saham, sedangkan Dividen Payout Ratio berpengaruh terhadap volatilitas harga saham. Selanjutnya terdapat penelitian oleh Fajrihan (2010) memperoleh hasil bahwa Dividen Payout Ratio dan Dividen Yield mempengaruhi volatilitas harga saham. Lashgari dan Ahmadi (2014) menunjukkan bahwa Dividen Payout Ratio tidak berpengaruh terhadap Volatilitas Harga Saham. Perbedaan studi di atas menunjukkan bahwa isu mengenai pengaruh kebijakan dividen terhadap harga saham masih memiliki perbedaan yang memperlukan klarifikasi ulang. 
Patricia Maurin Aten \& Dade Nurdiniah, DPR, dividend yield, stock price volatility, inflation...

Studi terbaru mengenai volatilitas harga saham juga memasukkan faktor makro ekonomi (Kohar, Ahmar, \& Suratno, 2019; Windari \& Nadir, 2020; Romli, Febrianti, \& Pratiwi, 2017; Widodo, 2020). Seperti kebijakan dividen, hasil penelitian mengenai faktor makro ekonomi (misalnya inflasi) juga menunjukkan bahwa inflasi secara signifikan mempengaruhi volatilitas harga saham (Kohar, Ahmar, \& Suratno, 2019; Windari \& Nadir, 2020), sedangkan studi lain menemukan yang meningkatkan kinerja positif yang tidak signifikan (Romli, Febrianti, \& Pratiwi, 2017) dan studi Widodo (2020) memiliki hasil yang berbeda pula sedangkan perbedaan negatif tidak signifikan terhadap volatilitas harga saham. Dalam konteks yang berbeda, inflasi juga banyak ditempatkan sebagai pemoderasi hubungan faktor fundamental perusahaan dengan harga saham (misalnya Irham, 2019; Maya, 2019). Memperhatikan hal tersebut, penelitian ini bertujuan untuk mengembangkan model hubungan kebijakan dividen dengan volatilitas harga saham dengan menempatkan inflasi sebagai pemoderasi.

Studi ini dapat berkontribusi pada isu volatilitas harga saham melalui beberapa hal: pertama, studi ini secara khusus menguhi pengaruh kebijkana dividen terhadap volatilitas harga saham (Kohar, Ahmar, \& Suratno, 2019; Windari \& Nadir, 2020; Romli, Febrianti, \& Pratiwi, 2017; Widodo, 2020) dengan menempatkan inflasi sebagai pemoderasi sebagai pengembagan dari studi sebelumnya (Irham, 2019; Maya, 2019). Kedua, penelitian ini mengambil sampel pada sektor manunfaktor, dan oleh karernanya hasil studi dapat berkontribusi pada pembuktian terbaru pada isu volatilitas harga saham. Hasil studi ini dapat bermanfaat dari sisi teoritis sebagai bukti empiris terbaru, dan praktis sebagai informasi bagi manajer dan calon investor dalam kebijakan investasi.

\section{KAJIAN PUSTAKA}

\section{Volatilitas Harga Saham}

Volatilitas harga saham adalah naik turunnya harga saham di dalam bursa efek. Pasar modal cenderung mengalami fluktuasi dan volatilitas yang tinggi karena jenis pasarnya sensitif terhadap informasi dan saham yang mudah berpindah tangan. Volatilitas harga tertinggi biasanya terdapat pada pair GBP/ USD, EUR/JPY, GBP/JPY, ataupun terkadang EUR/USD. Namun, besar-kecilnya volatilitas juga bisa berubahubah, ada jam-jam dimana volatilitas melambat. Semakin tinggi volatilitas, semakin banyak keuntungan yang bisa dipanen. Investor harus mampu menyusun strategi yang sesuai dengan kondisi pasar modal agar tidak mengalami kerugian.

Menurut Schwert dan Smith dalam penelitian Hugida dan Sofian (2011) terdapat lima jenis volatilitas dalam pasar uang, yaitu: (1) Future Volatility, adalah apa yang hendak diketahui oleh para investor. Volatilitas yang baik yaitu yang mampu menggambarkan penyebaran harga di masa yang akan datang. (2) Historical Volatility, dengan mempelajari masa lalu maka investor dapat memperkirakan masa depan harga saham. Dengan membuat permodelan harga berdasarkan data masa lalu investor dapat meramalkan volatilitas pada masa yang akan datang. Permodelan ini dapat menggunakan interval waktu dapat berupa harian, mingguan, bulanan, atau lainnya. (3) Forecast Volatility, berusaha meramalkan volatilitas masa depan suatu saham. (4) Implied Volatility, merupakan volatilitas yang harus kita masukkan untuk menghasilkan nilai teoritis yang identik dengan harga di pasar. (5) Seasonal Volatility, beberapa barang di komoditas pertanian sangat sensitif terhadap faktor volatilitas yang muncul dari kondisi cuaca musim yang jelek. Berdasarkan faktor tersebut seseorang harus menetapkan volatilitas yang tinggi pada masa-masa tersebut.

\section{Dividend Payout Ratio, Dividend Yield dan volatilitas harga saham}

Dividend payout ratio adalah presentase laba bersih yang telah dikurangkan dengan pajak yang akan diberikan kepada pemegang saham dalam bentuk dividen. Besarnya rasio berbanding terbalik dengan besarnya laba ditahan yang digunakan untuk aktivitas investasi perusahaan (Sudana, 2015: 167). Pemegang saham dan investor akan mencari perusahaan dengan dividend payout ratio yang tinggi karena akan menguntungkan pihaknya. 
Dividend yield merupakan rasio keuangan yang menggambarkan berapa nilai keuntungan atau tingkat pengembalian nilai investasi yang dibagikan oleh perusahaan kepada pemegang saham. Dividend Yield adalah salah satu faktor yang menjadi pertimbangan investor sebelum berinvestasi. Investor akan mencari perusahaan dengan Dividend Yield yang tinggi. Dividend yield merupakan rasio keuangan yang menggambarkan berapa nilai keuntungan atau tingkat pengembalian nilai investasi yang dibagikan oleh perusahaan kepada pemegang saham. Dividend Yield adalah salah satu faktor yang menjadi pertimbangan investor sebelum berinvestasi. Investor akan mencari perusahaan dengan Dividend Yield yang tinggi. Dividend yield merupakan rasio keuangan yang menggambarkan berapa nilai keuntungan atau tingkat pengembalian nilai investasi yang dibagikan oleh perusahaan kepada pemegang saham. Dividend Yield adalah salah satu faktor yang menjadi pertimbangan investor sebelum berinvestasi. Investor akan mencari perusahaan dengan Dividend Yield yang tinggi.

Rasio pembayaran dividen (dividend payout ratio) merupakan proporsi pendapatan yang dibayarkan sebagai dividen kepada pemegang saham, biasanya dinyatakan sebagai persentase. Beberapa perusahaan membayar semua pendapatan mereka kepada pemegang saham, sementara beberapa hanya membayar sebagian dari pendapatan mereka. Jika sebuah perusahaan membayar sebagian dari pendapatannya sebagai dividen, bagian yang tersisa akan disimpan sebagai laba ditahan untuk pengembangan perusahaan. Dividend payout ratio yang tinggi cenderung akan membuat investor tertarik untuk melakukan investasi. Beberapa studi seperti Azura, Sofia, Nurhasanah (2018); Priana. \& Muliartha (2017); Rohmawati (2017). menunjukkan hasil bahwa Dividen Payout Ratio berpengaruh terhadap volatilitas harga saham.

\section{Inflasi dan volatilitas harga saham}

Menurut Murni (2013: 202) inflasi adalah suatu kejadian yang menunjukkan kenaikan tingkat harga secara umum dan berlangsung secara terus menerus. Bank Indonesia (BI) mendefinisikan inflasi sebagai kecenderungan harga-harga untuk meningkat secara umum dan terus menerus. Inflasi menyebabkan kerugian bagi perusahaan dimana biaya untuk produksi akan meningkat sedangkan pendapatan menurun karena daya beli masyarakat rendah. Adanya inflasi disebabkan karena hal-hal yang memicu terjadinya inflasi. Menurut Bank Indonesia (BI), faktor penyebab adanya inflasi ada 3 (tiga) macam, yaitu: Tekanan dari sisi penawaran; Tekanan dari sisi permintaan; dan Ekspektasi inflasi. Inflasi sendiri dapat dibedakan dalam beberapa jenis yaitu, inflasi moderat, inflasi ganas dan hiperinflasi.

\section{METODE PENELITIAN}

Pendekatan yang dilakukan untuk menjelaskan hubungan antara variabel dalam penelitian adalah adalah kuantitatif, dimana data diperoleh dari sumber sekunder. Data sekunder yang digunakan berupa laporan keuangan dan laporan tahunan perusahaan manufaktur yang terdaftar di Bursa Efek Indonesia periode 2013-2017. Data-data yang akan diteliti yaitu harga per lembar saham, keuntungan per lembar saham, harga saham tertinggi dan terendah perusahaan dalam tahun $\mathrm{n}$, dan indeks harga konsumen tahun n. Data-data tersebut diperoleh dari situs resmi Bursa Efek Indonesia yaitu http:// www.idx.co.id, http:// www.idnfinancial.co.id dan website resmi perusahaan.

Pada penelitian ini, populasi penelitian adalah seluruh perusahaan manufaktur yang terdaftar di Bursa Efek Indonesia periode 2013-2017. Sampel dalam penelitian ini diambil menggunakan teknik purposive sampling yaitu teknik penentuan sampel dengan pertimbangan tertentu. Adapun kriteria sampel yang berlaku adalah: (1) Perusahaan manufaktur yang terdaftar di Bursa Efek Indonesia pada periode 2013-2017; (2) Perusahaan manufaktur yang terdaftar selama 5 tahun berturut-turut dari tahun 2013-2017; (3) Perusahaan manufaktur yang tanggal IPO setelah 1 Januari 2013; (4) Perusahaa manufaktur yang memiliki laporan keuangan dan laporan tahunan yang telah diaudit dari tahun 20132017. (5) Perusahaan manufaktur yang memiliki tanggal tutup buku 31 Desember; dan (6) Perusahaan manufaktur yang membayarkan dividen selama 5 tahun berturut-turut dari tahun 2013-2017 


\section{Operasional Variabel}

Dividend Payout Ratio

Variabel ini diukur dengan membagi jumlah dividen yang dibagikan ke pemegang saham per lembarnya, dengan laba bersih perusahaan per lembar saham, lalu dikali dengan 100\%. Jika dituliskan, maka rumusnya :

$$
\mathrm{DPR}=\frac{\text { Dividen per lembar saham }}{\text { laba bersih per lembar saham }}
$$

Dividend Yield

Variabel ini diukur dengan cara melakukan pembagian antara jumlah dividen yang dibagikan ke pemegang saham per lembarnya, dengan harga saham biasa per lembarnya. Jika dituliskan, maka rumusnya adalah sebagai berikut:

$$
\mathrm{DY}=\frac{\text { Dividend per Share }}{\text { Share Price }}
$$

Inflasi

Variabel ini diukur dengan mengurangkan Indeks Harga Konsumen pada waktu (bulan atau tahun) (n) dengan Indeks Harga Konsumen pada waktu (bulan atau tahun) (n-1) lalu hasilnya dibagi dengan Harga Konsumen pada waktu (bulan atau tahun) (n-1), dikali 100\%. Jika dituliskan, maka rumusnya adalah sebagai berikut.

$$
\mathrm{INFn}=\frac{I H K n-I H K n-1}{H K N-1} \times 100 \%
$$

Dimana:

INFn : inflasi atau deflasi pada waktu (bulan atau tahun) (n)

IHKn : Indeks Harga Konsumen pada waktu (bulan atau tahun) (n)

IHKn-1 : Indeks Harga Konsumen pada waktu (bulan atau tahun) (n-1)

HKn-1 : Harga Konsumen pada waktu (bulan atau tahun) (n-1)

\section{HASIL DAN PEMBAHASAN}

\section{Statistik deskriptif}

Lingkup pengumpulan sampel adalah perusahaan manufaktur yang terdaftar di BEI yang menerbitkan laporan keuangan tahunan pada tahun 2013-2017, sehingga mempunyai populasi 163 perusahaan. Berdasarkan kriteria dalam menentukan sampel dengan teknik purposive sampling, maka diperoleh jumlah sampel sebanyak 44 perusahaan selama 5 tahun pengamatan periode 2013-2017, dengan jumlah 220 data pengamatan. Uji yang dilakukan yaitu uji asumsi klasik untuk mengetahui apakah data penelitian normal dan bebas dari masalah. Uji asumsi klasik terdiri dari uji normalitas, uji multikolinearitas, uji heteroskesdastisitas dan uji autokorelasi. Lalu uji hipotesis yang dilakukan menggunakan analisis regresi berganda, moderated regression analysis, uji koefisien determinasi dan uji parsial (uji t). Terdapat singkatan dalam hasil uji menggunakan SPSS, yaitu PVOL (Volatilitas Harga Saham), DPR (Dividend Payout Ratio), DY (Dividend Yield), IF (Inflasi), DPRIF (hasil perkalian dari Dividend Payout Ratio dan Inflasi), DYIF (hasil perkalian dari Dividend Yield dan Inflasi).

Tabel 1 Statistik Deskriptif 


\begin{tabular}{lrrrrr}
\hline & N & Minimum & Maximum & \multicolumn{1}{c}{ Mean } & Std. Deviation \\
\hline DPR & 220 &, 20 &, 99 &, 6163 &, 19293 \\
DY & 220 &, 04 &, 25 &, 1526 &, 04932 \\
\hline PVOL & 220 &, 14 &, 86 &, 4540 &, 12365 \\
\hline IF & 220 & 1,74 & 2,89 & 2,2509 &, 52810 \\
Valid N (listwise) & 220 & & & &
\end{tabular}

Tabel 1 menggambarkan deksripsi statistik untuk masing-masing variabel yang digunakan. Dari tabel di atas dapat dilihat bahwa: variabel independen yang pertama (X1) yaitu Dividend Payout Ratio berdasarkan hasil uji descriptive statistics memiliki nilai minimum adalah 0,20 dan nilai maksimum adalah 0,99, nilai rata-rata (mean) dari Dividend Payout Ratio adalah 0,6163, sedangkan standar deviasi dari Dividend Payout Ratio sebesar 0,19293. Variabel independen yang kedua (X2) yaitu Dividend Yield berdasarkan hasil uji descriptive statistics memiliki nilai minimum adalah 0,04 dan nilai maksimum adalah 0,25, nilai rata-rata (mean) dari Dividend Yield adalah 0,1526, sedangkan standar deviasi dari Dividend Yield sebesar 0,04932. Variabel dependen (Y) yaitu Volatilitas Harga Saham berdasarkan hasil uji descriptive statistics memiliki nilai minimum adalah 0,14 dan nilai maksimum adalah 0,86 , nilai ratarata (mean) dari Volatilitas Harga Saham adalah 0,4540, sedangkan standar deviasi dari Volatilitas Harga Saham sebesar 0,12365. Variabel moderasi Inflasi berdasarkan hasil uji descriptive statistics memiliki nilai minimum adalah 1,74 dan nilai maksimum adalah 2,89 , nilai rata-rata (mean) dari Inflasi adalah 2,2509, sedangkan standar deviasi dari Inflasi sebesar 0,52810.

\section{Uji Asumsi Klasik}

Uji Normalitas

Uji normalitas yang digunakan dalam penelitian ini adalah uji normal probability plot, uji ini membandingkan distribusi kumulatif dari distribusi normal, dimana distribusi normal akan membentuk garis lurus diagonal dan ploting data residual akan dibandingkan dengan garis diagonal tersebut. Jika distribusi variabel residual normal, maka garis yang menggambarkan variabel sesungguhnya akan mengikuti garis diagonalnya.

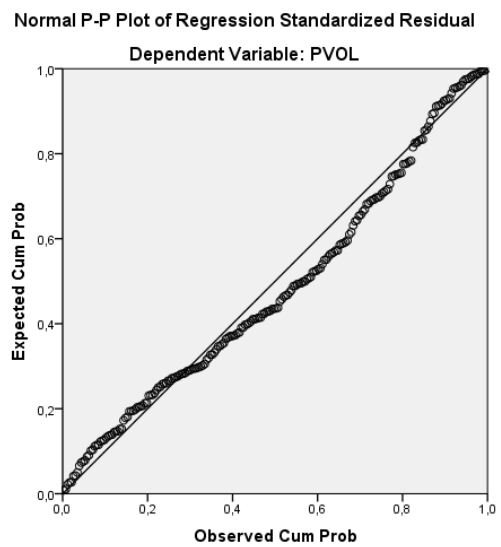

Gambar 1 Uji Normalitas

Berdasarkan grafik uji p-plot maka dapat disimpulkan data berdistribusi normal, terlihat titik-titik yang mewakili sampel data berkumpul mendekati garis diagonal. 
Patricia Maurin Aten \& Dade Nurdiniah, DPR, dividend yield, stock price volatility, inflation...

Uji Multikolinieritas

Uji multikolinearitas dilihat dari nilai Tolerance dan VIF. Apabila nilai Tolerance lebih dari 0,01 dan nilai VIF kurang dari 10, maka tidak terjadi multikolinearitas. Suatu data yang baik adalah data yang tidak terdapat multikolinearitas. Berikut adalah hasil uji multikolinearitas dengan menggunakan SPSS. Hasil tolerance dari masing-masing variabel Dividend Payout Ratio, Dividend Yield dan Inflasi bernilai $>0,10$ dan nilai VIF $<10$ yang berarti tidak terjadi multikolinearitas antar variabel independennya.

Uji Heteroskedastisitas

Uji heterokedastisitas bertujuan menguji apakah dalam model regresi terjadi ketidaksamaan variance dari residual satu pengamatan ke pengamatan yang lain. Model regresi yang ideal adalah homokedastisitas, yaitu kondisi dimana variance dari residual satu pengamatan ke pengamatan lain tetap, dan jika hasilnya berbeda disebut heteroskedastisitas (Ghozali, 2018:137). Penelitian ini dilakukan dengan menggunakan Uji Glejser. Hasil dari uji glejser diatas dapat diketahui bahwa nilai signifikansi dari variabel Dividend Payout Ratio, Dividend Yield dan Inflasi lebih besar dari 0,05. Hal ini menunjukkan bahwa pada penelitian ini tidak terdapat heteroskedastisitas.

Uji Autokorelasi

Uji autokorelasi bertujuan untuk menguji apakah dalam model regresi linier terdapat korelasi antara kesalahan pengganggu pada periode $t$ dengan kesalahan pengganggu pada periode $t_{-1}$. Autokorelasi muncul karena adanya keterkaitan antara observasi yang berurutan sepanjang waktu (Ghozali, 2018:111). Penelitian ini dilakukan dengan menggunakan uji Runs Test. Nilai sig sebesar 0,787>0,05. Hal ini berarti tidak terdapat autokorelasi dalam penelitian ini.

\section{Uji Hipotesis}

Penelitian ini menggunakan analisis regresi linear berganda karena memiliki variabel independen lebih dari 1. Penelitian ini juga menggunakan moderated regression analysis karena memiliki variabel moderasi.

PVOL $=0,549-0,116 D P R-0,152 D Y$

\section{Model MRA}

PVOL $=0,761-0,301 \mathrm{DPR}-0,550 \mathrm{DY}-0,097 \mathrm{IF}+0,085 \mathrm{DPRIF}+0,182 \mathrm{DYIF}$

Tabel 2. Hasil Uji t MRA

\begin{tabular}{lllll}
\hline Variabel & Koefisien & T value & Sig & Kesimpulan \\
\hline C & 0.761 & & & \\
DPR & -0.301 & -1.438 & 0.152 & Tidak Signifikan \\
DY & -0.550 & -0.680 & 0.497 & Tidak Signifikan \\
IF & -0.097 & -1.593 & 0.113 & Tidak Signifikan \\
DPR*IF & 0.085 & 0.908 & 0.365 & Tidak Signifikan \\
DY*IF & 0.182 & 0.522 & 0.602 & Tidak Signifikan \\
\hline
\end{tabular}

Berdasarkan hasil uji statistik t nilai sig yang diperoleh untuk variabel Dividend Payout Ratio sebesar 0,022 lebih kecil dari 0,05 maka dapat disimpulkan bahwa $\mathrm{H}_{1}$ diterima. Artinya terdapat pengaruh Dividend Payout Ratio (X1) terhadap volatilitas harga saham (Y). Hasil yang positif ini menunjukkan bahwa rasio pembayaran dividen berbanding lurus dengan volatilitas harga saham. Semakin tinggi tingkat rasio pembayaran dividen maka volatilitas harga saham pun akan meningkat. Pemegang saham sangat memperhatikan tingkat pembayaran dividen suatu perusahan beserta besarnya nilai yang 
dibayarkan, seberapa besar nilai yang disisihkan oleh perusahaan dari laba bersih untuk kepentingan pemegang saham akan memberikan nilai tambah dan meningkatkan loyalitas pemegang saham.

Penelitian ini memperoleh hasil nilai sig sebesar 0,275 >0,05, maka dapat disimpulkan bahwa Dividend Yield tidak berpengaruh terhadap volatilitas harga saham dan $\mathrm{H}_{2}$ ditolak. Dividend Yield sendiri melihat pembayaran dividen dari sudut pandang yang berbeda, pemegang saham lebih memperhatikan seberapa besar pengembalian yang ia terima dari kekayaannya yang diinvestasikan. Hal ini menunjukkan bahwa pemegang saham hanya memperhatikan besarnya return dari laba perusahaan dibandingkan dengan jumlah kekayaan awalnya, kondisi ini dinilai lebih aktual untuk menilai keuntungan pembagian dividen oleh perusahaan. Nilai investasi awalnya bersifat statis dan tidak akan menjadi pembanding yang ideal.

Penelitian akan variabel moderasi dengan pengaruh kedua variabel lainnya dilakukan dengan uji MRA. Hasil yang diperoleh adalah Inflasi tidak memoderasi pengaruh antara Dividend Payout Ratio terhadap Volatilitas Harga Saham. Pada saat inflasi menyentuh angka tinggi harga barang akan naik dan perusahaan harus mengeluarkan biaya lebih untuk produksi namun belum tentu tingkat konsumsi pasar juga ikut meninggi sehingga sulit untuk memperoleh untung dan melakukan pembagian dividen. Perusahaan dengan rasio pembagian dividen yang tidak stabil dan jumlah yang tidak dapat diprediksi menjadi salah satu alasan investor enggan membeli saham perusahaan tersebut, dengan begitu tidak terjadi aktivitas yang menimbulkan perubahan harga saham, kemungkinan yang terjadi adalah hanya penurunan harga saham. Belum ada penelitian terdahulu yang meneliti tentang inflasi yang memoderasi pengaruh DPR terhadap volatilitas harga saham, namun inflasi diketahui memiliki pengaruh baik terhadap volatilitas harga saham maupun DPR.

Hasil yang diperoleh dari uji MRA adalah Inflasi tidak memoderasi pengaruh antara Dividend Yeld terhadap Volatilitas Harga Saham. Pada dasarnya dalam penelitian ini Dividend Yield tidak mempengaruhi Volatilitas Harga Saham sehingga kehadiran variabel Inflasi semakin mempertegas jarak antara kedua variabel yang diuji ini. Namun jika dijabarkan dalam suatu pengandaian antara ketiga variabel ini maka dapat dijelaskan sebagai berikut, besarnya pengembalian yang diperoleh oleh investor dari kekayaan yang sudah diinvestasikannya akan menjadi pusat perhatian investor karena itu menunjukkan kinerja perusahaan dalam memanfaatkan investasi yang diperoleh dan bagaimana timbal balik perusahaan terhadap investor itu sendiri. Tingkat inflasi per tahunnya akan memberi yang dampak luas bagi suatu negara, inflasi yang terlalu rendah atau terlalu tinggi bisa menjadi ancaman bagi perekonomian negara tersebut, dalam hal ini inflasi yang tidak wajar akan menyebabkan pengembalian perusahaan kepada investor tidak dapat dilakukan sehingga menyebabkan perubahan harga saham tidak bervariasi.

\section{KESIMPULAN}

\section{Kesimpulan}

Berdasarkan penelitian yang telah dilakukan, maka kesimpulan sebagai berikut: pertama, dividend Payout Ratio berpengaruh terhadap Volatilitas Harga Saham. Rasio pembayaran dividen suatu perusahaan beserta besarnya nilai saham yang dibagikan dari keseluruhan laba yang diperoleh perusahaan akan mempengaruhi perubahan harga saham perusahaan di pasar saham. Kedua, dividend Yield tidak berpengaruh terhadap volatilitas harga saham. Nilai dividen yang dibagikan berdasarkan sudut pandang besar pengembalian yang investor terima dari kekayaannya yang diinvestasikan tidak mempengaruhi perubahan harga saham perusahaan di pasar saham. Ketiga, inflasi tidak memoderasi pengaruh antara Dividend Payout Ratio terhadap volatilitas harga saham. Perubahan tingkat inflasi per tahunnya memperlemah pengaruh antara Dividend Payout Ratio terhadap volatilitas harga saham. Terakhir, inflasi tidak memoderasi pengaruh antara Dividend Yield terhadap volatilitas harga saham. Perubahan tingkat inflasi per tahunnya memperlemah pengaruh antara Dividend Yield terhadap Volatilitas Harga Saham. 
Patricia Maurin Aten \& Dade Nurdiniah, DPR, dividend yield, stock price volatility, inflation...

Rasio pembayaran dividen adalah proporsi pendapatan yang dibayarkan sebagai dividen kepada pemegang saham, biasanya dinyatakan sebagai persentase. Beberapa perusahaan membayar semua pendapatan mereka kepada pemegang saham, sementara beberapa hanya membayar sebagian dari pendapatan mereka. Jika sebuah perusahaan membayar sebagian dari pendapatannya sebagai dividen, bagian yang tersisa akan disimpan oleh bisnis. Beberapa pertimbangan digunakan untuk menginterpretasikan rasio pembayaran dividen, yang paling penting adalah tingkat kematangan perusahaan. Perusahaan baru yang berorientasi pada pertumbuhan yang bertujuan untuk memperluas, mengembangkan produk baru, dan pindah ke pasar baru akan diharapkan untuk menginvestasikan kembali sebagian besar atau semua pendapatannya dan dapat dimaafkan karena memiliki rasio pembayaran yang rendah atau bahkan nol. Rasio pembayaran adalah $0 \%$ untuk perusahaan yang tidak membayar dividen dan 100\% untuk perusahaan yang membayar seluruh laba bersih sebagai dividen.

\section{Keterbatasan}

Penelitian ini mempunyai beberapa keterbatasan terutama dari sisi sampel dan hasil studi yang tidak berhasil membuktikan seluruh hipotesis. Riset berikutnya disarankan untuk memperluas populasi dan sampel penelitian yang akan dilakukan tidak hanya dari sektor non keuangan saja, dengan cara menambah variasi populasi dengan mengikutsertakan sektor keuangan. Penelitian lanjutan juga dapat mempertimbangkan faktor lain seperti volume perdagangan, ukuran perusahaan dan leverage sebagai determinan harga saham.

\section{REFERENSI}

Ahmad, M. A., Alrjoub, A. M. S., Alrabba, H. M. (2018). The Effect of Dividend Policy on Stock Price Volatility: Empirical Evidence from Amman Stock Exchange. Academy of Accounting and Financial Studies Journal Vol. 22, Num. 2.

Ambarwati, S. D. A. (2010). Manajemen Keuangan Lanjut Edisi 1. Yogyakarta: Graha Ilmu.

Andriyani. (2017). Pengaruh Kebijakan Dividen Terhadap Nilai Perusahaan Pada Perusahaan Manufaktur Yang Terdaftar di Bursa Efek Indonesia. Surakarta : Universitas Muhammadiyah

Azura, S. N., Sofia, M., \& Nurhasanah. (2018). Faktor-Faktor yang Mempengaruhi Volatilitas Harga Saham pada Perusahaan Manufaktur yang Tercatat di Bursa Efek Indonesia. Kepulauan Riau : Universitas Maritim Raja Ali Haji.

Brigham, E. F., \& Houston, J. F. (2014). Dasar-dasar Manajemen Keuangan. Jakarta: Salemba Empat.

Darmadji, T., \& Fakhruddin, H.M. (2012). Pasar Modal Di Indonesia Edisi Ketiga.Jakarta: Salemba Empat.

Fahmawati, A.A. (2017). Hubungan Kebijakan Dividen (Dividend Yield dan Dividend Payout Ratio) Terhadap Volatilitas Harga Saham Pada Perusahaan Manufaktur Yang Terdaftar di Bursa Efek Indonesia. Surakarta : Universitas Muhammadiyah.

Fahmi, I. (2015). Pengantar Manajemen Keuangan Teori dan Soal Jawab. Bandung: Alfabeta.

Fajrihan, J. (2010). Dampak Kebijakan Dividen Terhadap Volatilitas Harga Saham Perusahaan LQ45 di BEI.Jakarta : UIN Syahid.

Ghozali, I. (2018). Aplikasi Analisis Multivariate dengan Program IBM SPSS 25. Semarang: Badan Penerbit Universitas Diponegoro.

Hashemijoo, M., Ardekani, A. M., \& Younesi, N. (2012). The Impact of Dividend Policy on Share Price Volatility in the Malaysian Stock Market. Journal of Business Studies Quarterly, Vol. 4, No. 1, 111 129.

Irham, D. (2019). Pengaruh rasio leverage terhadap return saham dengan inflasi sebagai variabel moderasi: Studi pada perusahaan sub sektor makanan dan minuman yang terdaftar di BEI periode 2013-2018 (Doctoral dissertation, Universitas Islam Negeri Maulana Malik Ibrahim).

Khan, M. I., Khan, M. A., Meher, M., \& Syed, S. M. K. (2013). Impact of Ination on Dividend Policy: Synchronization of Capital Gain and Interest Rate. MPRA Paper No. 51593.

Kharinda, F. E. G. (2018). Pengaruh Dividen Payout Ratio, Leverage, Profitabilitas, dan Perilaku Follower Investor Terhadap Volatilitas Harga Saham pada Perusahaan Pertambangan yang Terdaftar di Bursa Efek Indonesia. Lampung: Universitas Lampung. 
Khurniaji, A. W., \& Raharja. (2013). Hubungan Antara Kebijakan Deviden Terhadap Volatilitas Harga Saham di Perusahaan-Perusahaan yang Terdaftar di Bursa Efek Indonesia. Diponegoro Journal of Accounting Vol.2 No.3, 1.

Kohar, A., Ahmar, N., \& Suratno, S. (2019). Sensitivitas Faktor Ekonomi Makro Dan Mikro Dalam Memprediksi Volatilitas Harga Saham Perusahaan Sektor Industri Food \& Beverages. JIAFE (Jurnal Ilmiah Akuntansi Fakultas Ekonomi), 4(1), 85-100.

Lashgari, Z \& Ahmadi. (2014). The Impact Of Dividend Policy On Stock Price Volatility In The Tehran Stock Exchange. Kuwait Chapter of Arabian Journal of Business and Management Review Vol. 3, No.10.

Maya, V. N. (2019). Pengaruh pertumbuahan ekonomi dan non performing financing terhadap profitabilitas dengan inflasi sebagai moderasi pada perbankan syariah di Indonesia tahun 20132018 (Doctoral dissertation, Universitas Islam Negeri Maulana Malik Ibrahim).

Priana, I. W. K., \& Muliartha, K. R. (2017). Pengaruh Volume Perdagangan Saham, Leverage, Dan Dividend Payout Ratio Pada Volatilitas Harga Saham. E-Jurnal Akuntansi Universitas Udayana, 20(1), 1-29.

Rafiqa. (2017). Analisis Pengaruh Kebijakan Dividen dan Pertumbuhan Perusahaan Terhadap Volatilitas Harga Saham pada Perusahaan Manufaktur yang Terdaftar di Bursa Efek Indonesia. Lampung: Universitas Lampung.

Rohmawati, I. (2017). Pengaruh Volume Perdagangan, Dividend Payout Ratio Dan Inflasi Terhadap Volatilitas Harga Saham Pada Perusahaan Yang Terdaftar Dalam Indeks LQ45 Tahun 2011-2015. Jurnal Pendidikan dan Ekonomi, 6(1), 38-45.

Romli, H., Febrianti, M., \& Pratiwi, T. S. (2017). Faktor-faktor yang mempengaruhi volatilitas harga saham pada PT Waskita Karya Tbk. Jurnal Ilmiah Ekonomi Global Masa Kini, 8(1), 1-5.

Rudianto. (2012). Pengantar Akuntansi Konsep dan Tekhnik Penyusunan Laporan Keuangan. Jakarta: Erlangga.

Selpiana, K. R., \& Badjra, I. B. (2018). Pengaruh Kebijakan Dividen, Nilai Tukar, Leverage, Dan Firm Size Terhadap Volatilitas Harga Saham. E-Jurnal Manajemen Unud, Vol. 7, No. 3, 1682-1712.

Surahmat, Swandari, F., \& Dewi, D. M. (2017). Pengaruh Kebijakan Dividen dan Faktor Lainnya Terhadap Volatilitas Harga Saham Perusahaan Pertambangan. Jurnal Wawasan Manajemen, Vol. 5, No. 2.

Spence, M. (1973). Job Market Signaling. The Quarterly Journal of Economics Vol. 87, No. 3, 355-374.

Tatang, A., \& Gumanti. (2013). Kebijakan Dividen: Teori, Empiris, dan Implikasi. Edisi 1. Yogyakarta: UPP STIMYKPN.

Widoatmodjo, A. (2015). Pengetahuan Pasar Modal Untuk Konteks Indonesia. Jakarta: PT Elex Media Komputindo.

Widodo, F. M. (2020). Analisis pengaruh price earning ratio, inflasi dan nilai kurs terhadap volatilitas harga saham pada industri manufaktur yang terdaftar di Bursa Efek Indonesia periode 2016-2018 (Doctoral dissertation, Widya Mandala Catholic University Surabaya).

Windari, T. A. E., \& Nadir, M. (2020). FAKTOR-FAKTOR YANG MEMPENGARUHI VOLATILITAS HARGA SAHAM STUDI PADA PERUSAHAAN INDEKS LQ45. Jurnal Ilmu Manajemen Mulawarman (JIMM), $4(2)$.

\section{PROFIL PENULIS}

Patricia Maurin Aten dan Dade Nurdiniah adalah mahasiswa dan dosen di Fakultas Bisnis Institut Teknologi dan Bisnis Kalbis

AKURASI: Jurnal Riset Akuntansi dan Keuangan, Vol 2, No.2, Agustus 2020, pp. 85 - 94 eISSN: $2685-2888$

Journal homepage: https:/ / ejournal.imperiuminstitute.org/ index.php/ AKURASI 